\title{
Multifunctional Phototherapy Device Design
}

\author{
Mehmet Akşahin \\ Department of Biomedical Engineering, Başkent University, Ankara, Turkey
}

Cite this article as: Akşahin M. Multifunctional Phototherapy Device Design. Electrica, 2019; 19(1): 65-71.

\section{ABSTRACT}

Today, phototherapy devices are used to treat newborn jaundice. However, there are some cases that the commercial phototherapy devices are inadequate. Most of the device are controlled only at the certain interval that prevents instantaneous monitoring the newborn's vital parameters. For other cases, devices are one-way lighting. In addition, when the baby is taken away from the device, unnecessary lighting causes the decrease in LED's lifetime. In the scope of the study, intensive phototherapy device was developed to eliminate deficiencies that are mentioned above. Properties of the developed phototherapy device are; Automatic detection of newborn's presence, double-sided illumination, continuous monitoring with IP webcam, temperature measurement of the environment and also newborn's body temperature. The light intensity of the device was measured with a photometer as $28.6 \mu \mathrm{W} / \mathrm{cm}^{2} / \mathrm{nm}$ that was obtained from $460 \mathrm{~nm}$ wavelength LED illumination in both top and bottom in accordance with the American Academy of Pediatrics (AAP) guideline.

Keywords: Neonatal Jaundice, Phototherapy, Multifunctional System Design and Control

\section{Corresponding Author:}

Mehmet Akşahin

E-mail:

maksahin@gmail.com

Received: 06.09.2018

Accepted: 18.12 .2018

(C) Copyright 2019 by Electrica

Available online at

http://electrica.istanbul.edu.tr

DOI: $10.26650 /$ electrica.2019.18022

\section{Introduction}

Fetal red blood cells (RBCs) are different from normal ones. These cells contain fetal Hemoglobin $(\mathrm{HbF})$. Red blood cells lose their function and start to disintegrate in a short period after birth. Thus, RBC's that contain new type hemoglobin $(\mathrm{HbA})$ begin to be produced. As a result of the disintegrated RBC's containing HbF, the excessive amount of bilirubin substance occurs as a by-product. In a healthy adult, liver transforms bilirubin in into a form to be thrown from the body [1]. However, liver function of newborn is not adequate to destroy the high amount of bilirubin. So, the bilirubin, which is needed to be thrown out of the body, starts to accumulate in the blood. Bilirubin has yellow-colored pigments. As a result of the excessive amount of bilirubin accumulation and penetration, the newborn's the skin and eyes to have a yellowish appearance. This condition is called the neonatal jaundice [2]. If the high level of bilirubin cannot be removed out of the newborn's body, it can be seen clinical consequences such as bilirubin encephalopathy, hearing loss and kernicterus [3]. In order to make non-conjugated bilirubin into water soluble form, phototherapy method is applied [4].

The phototherapy device which is used in the treatment of neonatal jaundice, is based on the principle that the conversion of the non-conjugated bilirubin that accumulated on the skin surface into a water-soluble form by applying light in the visible region (blue light $460 \mathrm{~nm}$ ). This non-invasive method is used and accepted by pediatricians for the treatment of neonatal jaundice [5]. The efficiency of phototherapy treatment depends on the factors like the surface area of the newborn (as the surface area increases, the total bilirubin decline rate increases), the spectral properties (460 $\pm 10 \mathrm{~nm}$ wavelength) and the irradiation (brightness, light intensity: body surface area per square meter) of the light source (The current AAP guidelines recommends a light intensity of at least $30 \mu \mathrm{W} / \mathrm{cm}^{2} / \mathrm{nm}$ for dense phototherapy under blue light and for the largest surface area), the distance between the light source and the newborn (The distance is at least $10 \mathrm{~cm}$, provided that the newborn's body temperature is constantly monitored.), the type of light source, the thickness and pigmentation of the skin, the total 
bilirubin level at the beginning of treatment and the duration of phototherapy [3, 5-10].

In this study, a completely original conceptual phototherapy device was designed and the prototype was produced in order to eliminate the deficiencies of the existing commercial devices. In the design phase, it is aimed to obtain intensive phototherapy by providing higher light efficiency than the existing commercial devices have. In this context, in order to increase the light efficiency of the device, light sources are placed both of on the top and bottom covers of the device. Moreover, detection of the newborn's existence in the device, the load cells are used. In addition, temperature measurements are made and an IP webcam can be integrated into the system to assist in monitoring the newborn by both of the hospital staff and also the parents.

\section{System Design}

The overall design of the phototherapy system is as shown in Figure 1. In the design, a microcontroller is used for controlling the sensors (heat and weight) in the hammock and the image formed on the IP webcam. Besides, the control of the LED's in the lighting array operation and the drive circuit are also provided with a microcontroller.

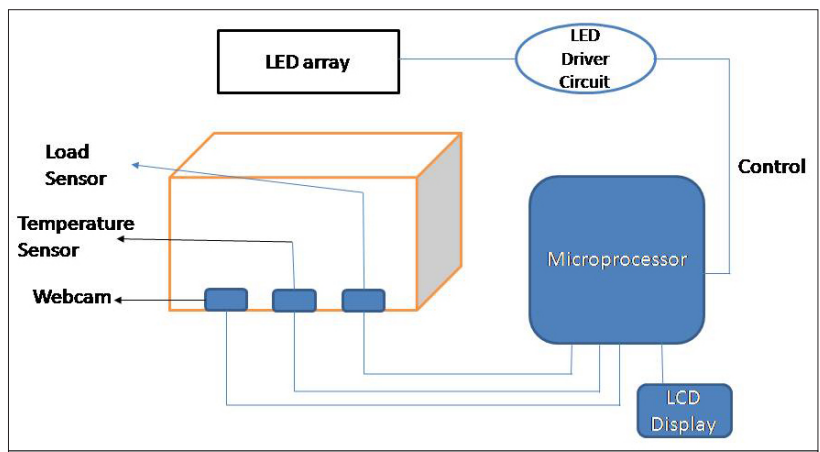

Figure 1. General block diagram of the device

\section{Lighting Calculations}

The luminous flux (lumen) is the amount of light that is delivered by a light source at the unit time and is calculated according to Equation 1 [11].

$$
\phi=4 * \pi * 1
$$

The luminous intensity (lux) is the intensity of light falling on the unit surface and is calculated according to Equation 2 [11].

$$
\mathrm{E}=\Phi / \mathrm{A}=4^{*} \pi^{*} 1 / 4^{*}
$$

$$
\pi^{*} r^{2} \quad=1 / r^{2}
$$

Light intensity is a parameter that also depends on the distance. The distance between the light source and target area is determined according to Equation 3 [11].

$$
\mathrm{I}=\mathrm{P} / 4 \pi \mathrm{r}^{2}
$$

In this equation, " $\mathrm{P}$ " is the maximum power of the light source to be used and " $r$ " is the distance between the light source and the target area. For the top and bottom illumination, the distance between light source and the hammock of the device is adjusted by the inverse square law as described in Equation 4 [11].

$$
\frac{I_{1}}{I_{2}}=\frac{d_{2}{ }^{2}}{d_{1}{ }^{2}}
$$

Here, "I" represents the luminous intensity at a certain distance and " $d$ " represents distance between the point where the intensity is known and the source. The current AAP guidelines recommend that the light intensity of blue light should be at least $30 \mu \mathrm{W} / \mathrm{cm}^{2} / \mathrm{nm}$ for the largest surface area for intensive phototherapy [3]. The distance between the light source to the infant is also calculated taking into account the AAP recommendation.

One of the most significant purposes of the preliminary design is to achieve a homogeneous distribution of light. For this purpose, the quantity and power of light sources must be determined correctly. In preliminary studies DIALuxevo simulation program is used for these calculations and the obtained illumination results are shown in Figure 2. Based on the obtained results, a light intensity of approximately $16 \mu \mathrm{W} / \mathrm{cm}^{2} / \mathrm{nm}$ was obtained with a 5-row, 7.5W (240 Lumens) strip LED (for one lighting side of the device). In this case the total light intensity for the upper and lower side of the design was set at a minimum of $32 \mu \mathrm{W} / \mathrm{cm}^{2} / \mathrm{nm}$.

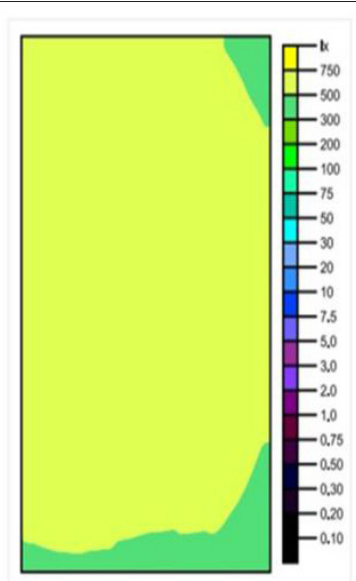

(a)

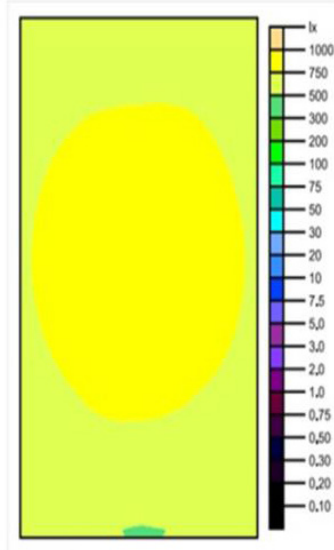

(b)
Figure 2. a-b. The surface area of the 4 Strip LEDs in lux units (Scale 1:10; vertical light surface; mean: 590lx; min: 395lx; max: 7031x; $\mathrm{min} /$ mean: $0.673 ; \mathrm{min} / \max : 0.565)$ (a). The surface area of the 5 Strip LEDs in lux units (Scale 1:10; vertical light surface; mean:7331x; min: 491lx; max: 8551x; min/mean: 0.670; min/max:0.574) (b) 


\section{Light source and Circuit design}

Power LEDs which have high lumen values are widely used in the lighting industry. In this study, Power Led's are used as a light source by virtue of the preliminary findings. To run the LED's with microprocessor, there must be an appropriate driver circuit and a power source. Figure 3 shows the block diagram of the LED system.

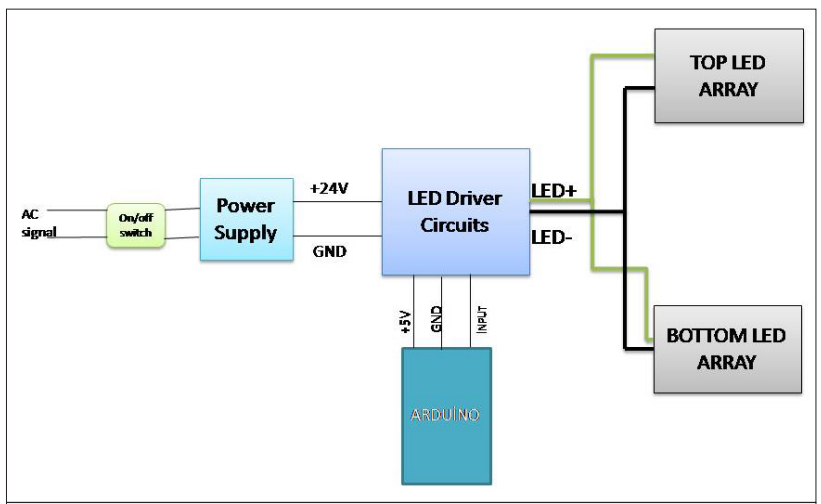

Figure 3. The block diagram of the LED System

The current levels of PowerLEDs are much higher than standard $5 \mathrm{~mm}$ diameter LEDs. It is required that 3.2 V for each PowerLED. By this, six of 460nm wave PowerLED's are series connected to draw about $350 \mathrm{~mA}$ current. The designed LED driver circuit is drawn and simulated in the Proteus program. The circuit that used to drive the LEDs is shown in Figure 4.

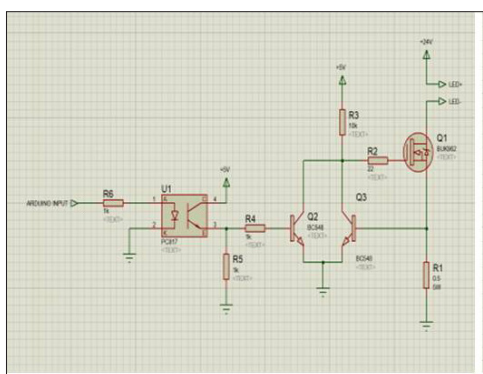

(a)

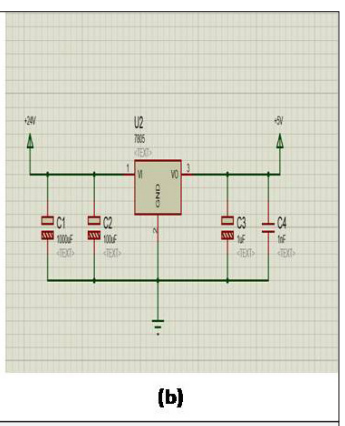

(b)
Figure 4. a-b. LED driver circuit (a) and voltage regulator (b)

In order to reduce the cost and the power consumption of the device, a $45^{\circ}$ lens was used to not only increase the focusing but also decrease in LED number that determined at the preliminary work. In the designed circuit, a total of 60 PowerLEDs were used as 30 on the top and 30 on the bottom. Six of them were formed in parallel with 5 parallel strips connected in series. $6 \times 5$ matrix was created on this count. The current in a single plate is $1.75 \mathrm{~A}$ and the total current from two plates is 3.5 A. The LED array of the device is shown in Figure 5.

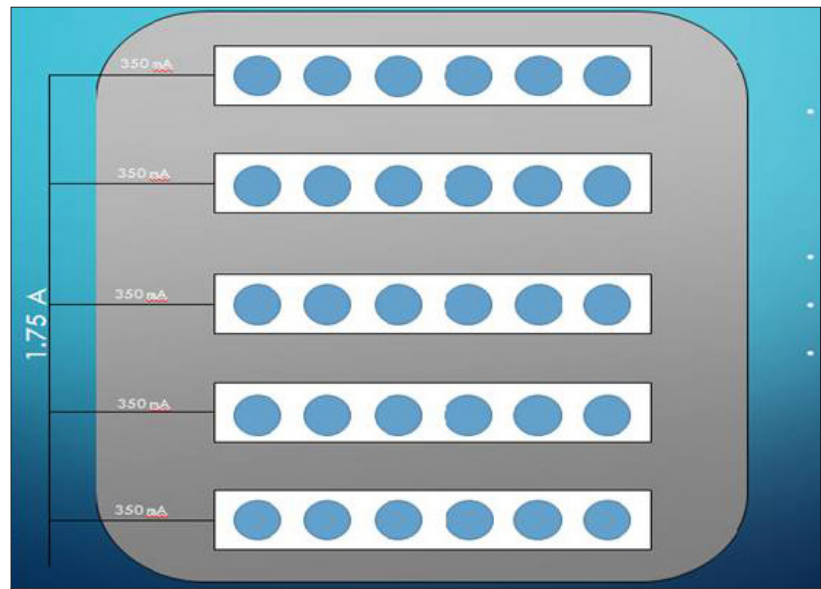

Figure 5. PowerLED array

\section{Control Circuit Design}

The control panel of the device was designed with a microprocessor-based circuit. The simulation of the circuit was made with Arduino Mega 2560 microprocessor card in Proteus shown in Figure 6. In the project, a load sensor is used to detect the newborn's existence in the device. For this purpose, a load cell has been integrated into the device control circuit and informed whether or not the baby is in the hammock has been determined through this sensor. The Load Cell generates a voltage output proportional to the pressure applied to it. The Load Cell's output is transferred to the Arduino board via the HX711 amplifier. When the weight information reached to the system, it is operated automatically.

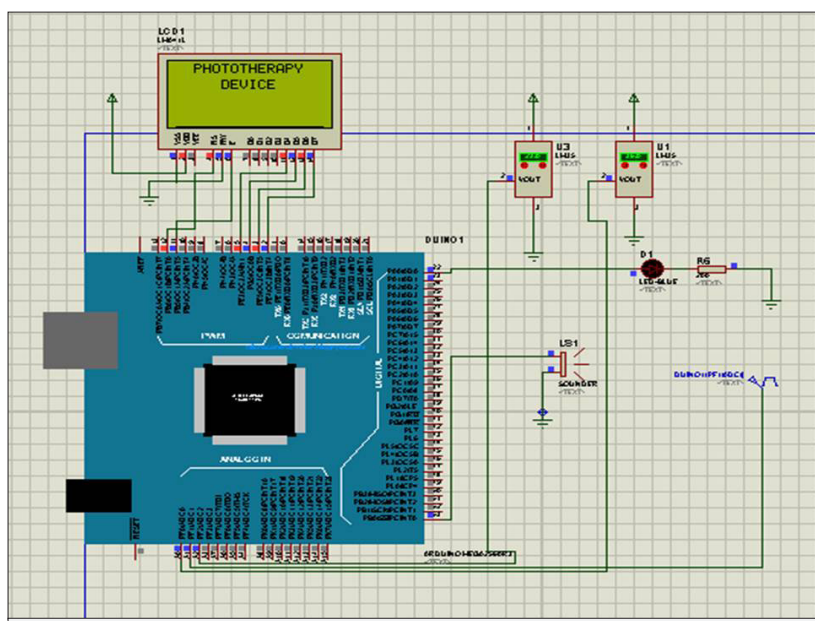

Figure 6. Device circuit

Instantaneous measurement of the ambient temperature was made with the digital temperature sensor DS18B20. The device uses a 20x4 LCD display to initiate the therapy, to adjust time and also to show warning information, ambient temperature and duration information. A buzzer has been used as an alert for 
the situations where the device should give a warning during therapy. The duration of the therapy is set using the UP/DOWN buttons on the control panel and shown on the display as unit of minutes. At the end of the duration, the device gives audible and written warnings. In cases where the baby needs to be taken from the device during the therapy, the system goes into the 'pause' mode as soon as the baby is taken from the device. If the baby is returned to the device within 2 minutes, the system continues to therapy. Otherwise, the device is automatically turned off and gives an audible and written warning. The body temperature measurement system was provided by integrating the circuit of an IR thermometer, which was supplied from the market, into the Arduino circuit. In this way, the relevant hospital staff can routinely make a contactless measure of the infant's body temperature with the temperature measurement key located on the control panel.

The housing of the device is designed and scribed in the SolidWorks program (Figure 7).

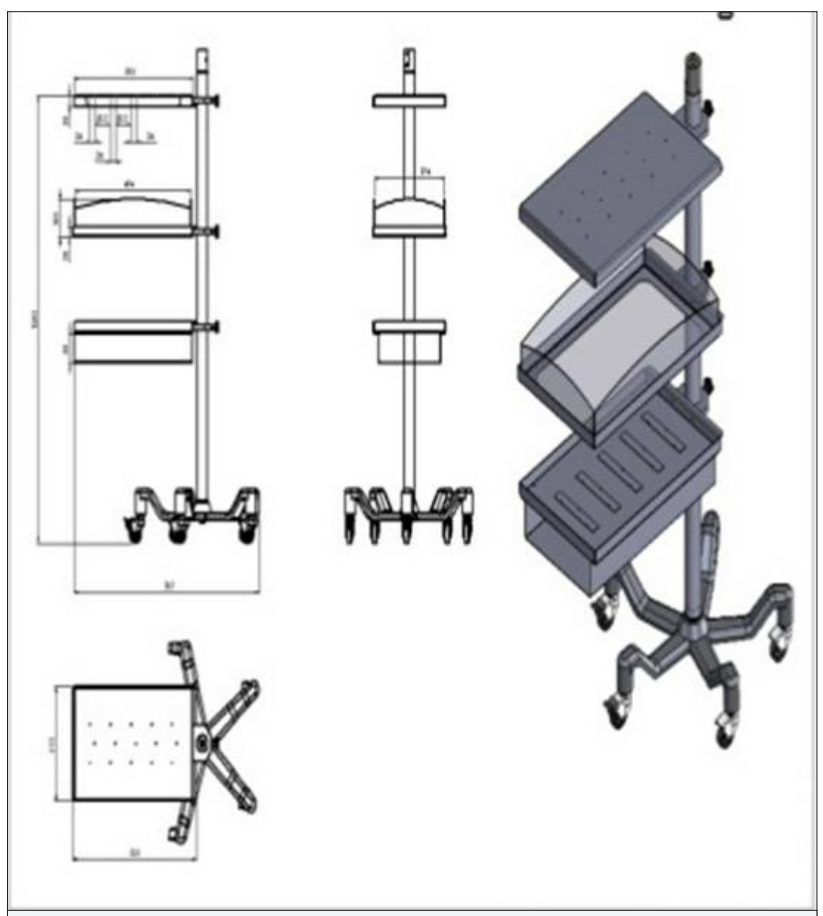

Figure 7. The housing of the device

\section{Results}

In this study, a phototherapy device that is used in the treatment of newborn jaundice was developed and a prototype was produced. The light intensity of the device was measured with a photometer and according to the AAP guide, light intensity of $28.6 \mu \mathrm{W} / \mathrm{cm}^{2} / \mathrm{nm}$ was obtained by LED ( $460 \mathrm{~nm}$ wavelength) illumination in both top and bottom.

The control and driver systems designed in the scope of the study are shown in Figure 8. The produced phototherapy device is shown in Figure 9.

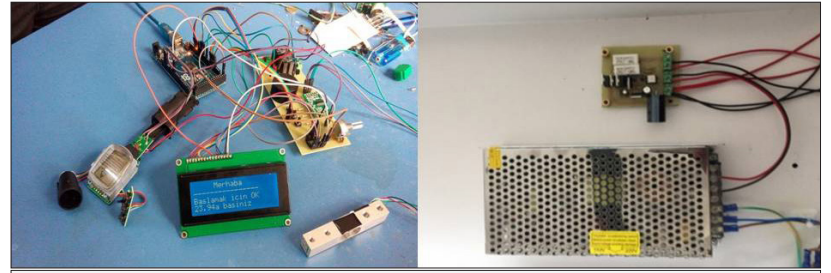

Figure 8. The control and driver systems

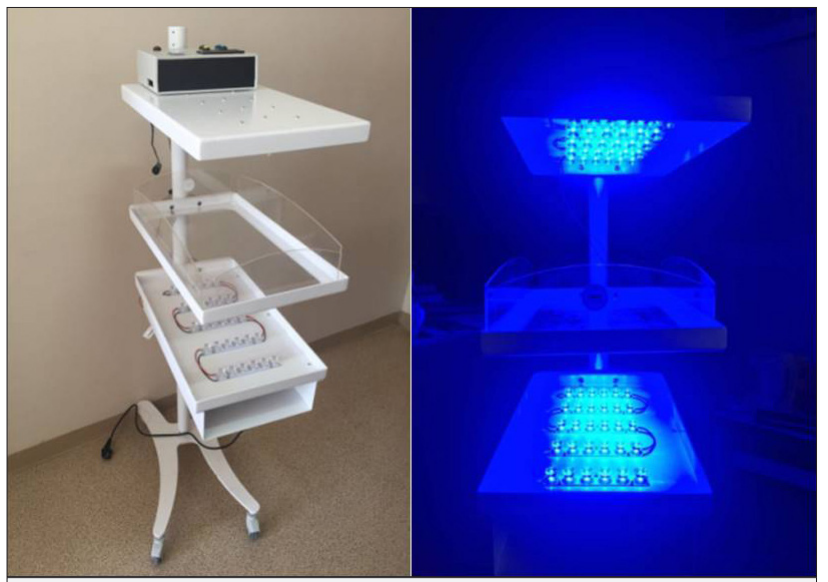

Figure 9. Phototherapy device

\section{Discussion}

The device prototype is designed as a double-sided lighting device. Since this will provide more effective treatment, it is thought to be able to shorten the duration and thence, increase the efficiency of the treatment.

With the use of a weight sensor that is not available in existing commercial systems, it is determined whether or not the baby is in the device and the system is automatically shut down when it is unnecessary. Thus, the lifetime of the light source will be prolonged and the efficiency of the device will be improved.

The biggest risk at the new born may encounter during phototherapy is eye damage, which is likely to result of the shift of the eye band. In order to prevent this condition, eyes are controlled at 4-6 hours intervals. Having such a long period of control is a particularly disturbing situation for parents. By the integration of The IP WEB cam, it is ensured that the baby can be monitored by both parents and health staff.

The developed system was compared with the similar commercial products in the market. Comparison is shown in Table 1. According to Table 1, the features of the presented phototherapy device are much more $[12,13,14,15]$. The power consumption of the developed device is very low, especially in comparison to its two-sided illuminating commercial products. Due to the use of power led, the system has up to 50000 hours of LED life [16]. However, as the energy consumption will be minimal due to the use of the weight sensor, the LED life of the developed device will be higher than its equivalent. 
Table 1. Properties of presented and commercial phototherapy devices in market

\begin{tabular}{|c|c|c|c|}
\hline Commercial Products & Technical Properties & Power Consumption & Cost \\
\hline $\begin{array}{l}\text { ERTUNÇ ÖZCAN BLUE ANGEL } \\
\text { LED PHOTOTHERAPY DEVICE } \\
{[12,13]}\end{array}$ & $\begin{array}{l}\text { - 450-470 Nm Narrow Beam Emitting Light Emitting } 24 \text { PCs Blue Led } \\
\text { - Unilateral lighting } \\
\text { - Focus light } \\
\text { - Baby skin temperature monitoring (optional) } \\
\text { - Up to 20,000 hours of LED life }\end{array}$ & 45Watt & $1000 \$$ \\
\hline $\begin{array}{l}\text { TENDE CAREBLUE-N LED } \\
\text { PHOTOTHERAPY DEVICE [13] }\end{array}$ & $\begin{array}{l}\text { - } 460 \text { Nm Narrow Beam Emitting Light Emitting } 24 \text { PCS Blue Led } \\
\text { - unilateral lighting } \\
\text { - Up to 20,000 hours of LED life } \\
\text { - Focus light }\end{array}$ & 45Watt & $1120 \$$ \\
\hline $\begin{array}{l}\text { TENDE BABYBLUE-N LED } \\
\text { PHOTOTHERAPY DEVICE [13] }\end{array}$ & $\begin{array}{l}\text { - } 460 \text { Nm Narrow Beam Emitting Light Emitting } 24 \text { PCS Blue Led } \\
\text { - unilateral lighting } \\
\text { - Up to 20,000 hours of LED life } \\
\text { - Focus light }\end{array}$ & 45Watt & $1000 \$$ \\
\hline $\begin{array}{l}\text { NOVOS BILISPHERE } 360 \text { LED } \\
\text { PHOTOTHERAPY DEVICE [13] }\end{array}$ & $\begin{array}{l}\text { - } 420 \text { - } 480 \text { Nm Narrow Beam Emitting Light Emitting } 16 \text { Pcs Led } \\
\text { - double sided lighting } \\
\text { - 20,000 hours of LED life }\end{array}$ & 266Watt & $5420 \$$ \\
\hline $\begin{array}{l}\text { OKUMAN BC } 250 \text { LCD LED } \\
\text { PHOTOTHERAPY DEVICE [13] }\end{array}$ & $\begin{array}{l}\text { - } 16 \text { PCs Led } \\
\text { - double sided lighting } \\
\text { - Up to } 50,000 \text { hours of LED life }\end{array}$ & 225Watt & $4450 \$$ \\
\hline $\begin{array}{l}\text { OKUMAN BC } 250000 \text { LED } \\
\text { PHOTOTHERAPY DEVICE [13] }\end{array}$ & $\begin{array}{l}\text { - } 16 \text { PCs Led } \\
\text { - double sided lighting } \\
\text { - Up to } 50,000 \text { hours of LED life }\end{array}$ & 225Watt & $3550 \$$ \\
\hline $\begin{array}{l}\text { neoBLUECozy LED } \\
\text { PHOTOTHERAPY DEVICE[14] }\end{array}$ & $\begin{array}{l}\text { - 450-470 Nm Narrow Beam Emitting Light Emitting } 24 \text { Pcs Blue Led } \\
\text { - unilateral lighting } \\
\text { - Up to } 20,000 \text { hours of LED life }\end{array}$ & 65Watt & $399 \$$ \\
\hline $\begin{array}{l}\text { Lullaby neoBLUECozy LED } \\
\text { PHOTOTHERAPY DEVICE [15] }\end{array}$ & $\begin{array}{l}\text { - 450-465 Nm Narrow Beam Emitting Light Emitting } 24 \text { Pcs Blue Led } \\
\text { - unilateral lighting } \\
\text { - Up to 50,000 hours of LED life }\end{array}$ & 20Watt & $720 \$$ \\
\hline $\begin{array}{l}\text { Presented LED } \\
\text { PHOTOTHERAPY DEVICE }\end{array}$ & $\begin{array}{l}\text { - } 460 \text { Nm Narrow Beam Emitting Light Emitting } 60 \text { Pcs Blue Led } \\
\text { - double sided lighting } \\
\text { - Focus light } \\
\text { - Up to 50,000 hours of LED life } \\
\text { - contactless baby skin temperature monitoring } \\
\text { - weight sensor } \\
\text { - Web cam baby monitoring }\end{array}$ & 65Watt & $150 \$$ \\
\hline
\end{tabular}

Moreover, the cost of the developed system is very low compared to the sales prices of the similar commercial products in the market. Additional features added to the phototherapy device, such as IP webcams and contactless baby temperature measurement, double the production cost of the system. But even with this cost increase, it is seen that the proposed system is produced at a much lower price than the similar commercial products in the market.

\section{Conclusion}

A multifunctional phototherapy device was developed to treat newborn jaundice. Properties of the developed photo- therapy device are; Automatic detection of newborn's presence, double-sided illumination, continuous monitoring with IP webcam, temperature measurement of the environment and also newborn's body temperature. The light intensity of the device was measured with a photometer as $28.6 \mu \mathrm{W} / \mathrm{cm}^{2}$ / $\mathrm{nm}$.

Peer-review: Externally peer-reviewed.

Conflict of Interest: The author have no conflicts of interest to declare.

Financial Disclosure: The author declared that the study has received no financial support. 


\section{References}

1. J.T. Benjamin "Neonatal Jaundice", Medical College of Georgia, 2008.

2. S. Öztürkcan, "Yenidoğan Derisinin Fizyolojik Özellikleri", Dermatolojide Yeni yaklaşımlar, Dermatose, vol. 2, no. 4, pp. 202-208, 2003.

3. Subcommittee on Hyperbilirubinemia, "Management of hyperbilirubinemia in the newborn infant 35 or more weeks of gestation", Pediatrics, vol. 114, no. 1, pp. 297-316, 2004. [CrossRef]

4. A. M. Hafkamp, "Oral treatment of unconjugated hyperbilirubinemia", University Library Groningen, 2006.

5. H. J. Vreman, R. J. Wong, D. K. Stevenson, "Phototherapy: current methods and future direction", In Seminars in perinatology, vol. 28, No. 5, pp. 326-333, WB Saunders, Oct, 2004.

6. N. Canbulat, M. Demirgöz, "Newborn's light treatment: Phototherapyh", Zeynep Kamil Tıp Bülteni, vol. 40, no. 1, pp. 37-41, 2009.

7. T. Dağoğlu, F. Ovalı, "İndirekt hiperbilirubinemi”, T. Dağoğlu, Neonataloji, İstanbul, Nobel Tıp Kitabevleri Ltd, 2000 vol, 50, pp. 453$455,2000$.

8. U. Demirsoy, "Indirekt Hiperbilirubinemi Nedeniyle Fototerapi Alan Term Yenidoğanlarda İntravenöz Sıvı Desteğinin Bilirubin Se- viyesi Üzerine Etkisi", Zeynep Kamil Women and Children Diseases Training and Research Hospital, İst, 2005.

9. G. Hart, R. Cameron, "The importance of irradiance and area in neonatal phototherapy", Archives of Disease in Childhood-Fetal and Neonatal Edition, vol. 90, no. 5, pp. F437-F440, 2005. [CrossRef]

10. P. Eggert, C. Stick, "The pattern of bilirubin response to phototherapy for neonatal hyperbilirubinemia", Pediatric research, vol. 18, no. 7, pp. 682, 1984. [CrossRef]

11. A. Mickelson, "Physical optics", Springer Science \& Business Media, 2012.

12. E. Özcan. (11.12.2018). Available: http://www.ertuncozcan.com/ images/dosyalar/Yeni_Dogan.pdf.

13. Devlet Malzeme Odası. (11.12.2018). Available:https://www.dmo. gov.tr/Katalog/Urun/Detay/1310_5645.

14. NeoBLUE cozy sistemi. (11.12.2018). Available:http://www.sgeyazilim.com/yonetimpaneli/upload/neoblue.pdf.

15. Colmed. (11.12.2018). Available: http://www.colmed.in/ge-lullaby-led-phototherapy-system.html.

16. Led Journal. Available: https://www.ledjournal.com/main/ wp-content/uploads/2012/05/Philips_Understanding-Power-LED-Lifetime-Analysis.pdf. 
Mehmet Feyzi Akşahin received the B.S degree in electrical and electronics engineering from Başkent University, and the Ph.D. degree in in electrical and electronics engineering from Middle East Technical University and Başkent University, Ankara, Turkey, in 2002, 2010 respectively. At 2003, he joined to Başkent University, biomedical engineering department as a research assistant. He made his postdoctoral study at the Roswell Park Cancer Institute, Buffalo, NY, USA in 2013. He has been working as an assistant professor at Başkent University, biomedical engineering since 2015. His research areas are signal processing, medical device design, intelligent systems and image processing. 